\title{
The Legal Status Regarding the Romanian Tax Executor
}

\author{
Alice Cristina Maria Zdanovschi \\ "Dimitrie Cantemir" Christian University, Bucharest, Romania, alice.zdanovschi@gmail.com
}

\begin{abstract}
This article focuses on the legal provisions governing the institution of the Romanian tax executor and aims to identify its legal status, by presenting its role and tasks in the tax execution procedure, and at the same time presents comparative aspects between the tax executor and the court executor. So, the forced execution of fiscal obligations is a way of extinguishing them. Furthermore, according to the special provisions existing in the field of taxation, when the taxpayers have not fulfilled their fiscal obligations at the date when they became due, the right of the state to pass to forced execution of the fiscal obligations is born on this date. And due to the enforceability of the title of the tax claim, the forced execution procedure carried out by the tax authorities is not preceded by another judicial procedure. Moreover, the tax authorities fulfill the forced execution procedure through tax executors, thus, the importance of its legal status is more than relevant compared to the "common law" executor in the Romanian legal system, which is the court executor.
\end{abstract}

KEYWORDS: court executor, enforceable title, forced execution, tax executor, taxpayer

\section{Introduction}

In Romania, in matters of forced execution, we encounter both common law provisions governing forced execution in the civil proceedings, regulated by the New Civil Procedure Code, republished (The new Code of Civil Procedure was adopted by Law no 134/2010 on the Code of Civil Procedure, published in the Official Gazette of Romania no 485/15.07.2010 and republished in the Official Gazette of Romania no 247/10.04.2015, regarding the evolution of this normative act), with subsequent modifications and completions, as well as special regulations, which concern this phase in other fields than the civil process (see, broadly Oprina 2007, 20; Zilberstein and Ciobanu 2001, 29-32, 72; Deleanu 2005, 426, 430-434; Leş 2005, 830; Oprina and Gârbuleţ 2013, 13 et seq), in particular, the special provisions of the Fiscal Procedure Code adopted by Law no 207/2015 on the Fiscal Procedure Code, as subsequently amended and supplemented, which is the base of the forced execution which aims at the recovery of fiscal obligations.

The special character of the Law no 207/2015 is conferred by the provisions of article 3 paragraph (2) of Code of Fiscal Procedure which stipulates that "where the present Code does not have the provisions, the provisions of the Civil Code and the Civil Procedure Code, republished, shall apply, in so far as they may be applicable to relations between public authorities and taxpayers". Therefore, the legal rules laid down in the Fiscal Procedure Code are derogations from the common law, represented by the New Civil Procedure Code, the principle specialia generalibus derogant being applicable.

And, furthermore, the provisions of paragraph (1) article 3 Code of Fiscal Procedure stipulates that the Code of Fiscal Procedure is the common law procedure for the administration of fiscal burdens due to the general budget. At the same time, the provisions of article 623 of the Civil Procedure Code enshrines the special legal regime of the provisions of the Code of Fiscal Procedure.

So, the forced execution of fiscal obligations is a way of extinguishing them. Furthermore, according to the special provisions existing in the field of taxation, when the taxpayers have not fulfilled their fiscal obligations at the date when they became due, the right of the state to pass to forced execution of the fiscal obligations is born on this date. And due to the enforceability of the title of the tax claim, the forced execution procedure carried out by the tax authorities is not preceded by another judicial procedure (Şaguna and Şova 2006, 59).

Thus, according to article 220 par. (1) Fiscal Procedure Code if the debtor does not voluntarily pay the tax obligations due, the competent fiscal body, for the extinction thereof, shall proceed to enforcement actions, according to the provisions of the Fiscal Procedure Code, unless 
there is a request for restitution / reimbursement in process of settlement, and the amount of the requested obligation is equal to or greater than the tax debt owed by the taxpayer. And, article 226 par. (1) - (2) Fiscal Procedure Code provides that forced execution of fiscal obligations shall be performed on the basis of an enforceable title issued according to the provisions of this Code by the competent enforcement body or by a writ which, according to the law, constitutes an enforceable title.

Enforced execution can only be carried out with the concurrence of the executing body (this is an authority invested by the state with the power to impose on the wanted debtor or on third persons, who own the goods, the obligation to execute the provisions contained in the enforceable title, in this respect, Oprina 2007, 50), the executing body being an indispensable participant in forced execution (Ciobanu and Boroi 2003, 448 apud Oprina 2007, 50). However, in the field of forced execution, in addition to the court executor, which is the executing body with full competence (Oprina 2007, 71, furthermore, the principle of the full competence of court executors is provided by the provisions of article 1 of the Law no 188/2000 regarding the court executors, republished, in the Official Gazette of Romania no 738 / 20.10.2011), we will also meet another executing body, namely the tax executor, operating under a special normative act, namely, Law no 207/2015 on the Fiscal Procedure Code.

According to article 220 par. (2) of the Fiscal Procedure Code, the fiscal body that manages the fiscal obligations is empowered to carry out the precautionary measures and carry out the forced execution procedure. And par. (3) stipulates that "the budgetary receivables which, according to the law, are administered by the public authorities or institutions, including those of own incomes, can be executed by tax executors organized in specialized departments, being empowered to carry out the precautionary measures and carry out the forced execution procedure, according to the provisions of this Code".

The organs presented in these two paragraphs are collectively referred to as "forced execution organs", according to par. (4) Article 220. Furthermore, these enforcement bodies are also competent to execute budget claims resulting from contractual legal relationships (in this respect, par. (5) Article 220 corroborated with the provisions of the par. (3) Article 226 Fiscal Procedure Code, where the enforceable title may be a court order or other document).

Thus, from the economics of fiscal texts, the persons within the enforcement bodies able to carry out the precautionary measures (regarding the legal status of the precautionary measures, see the provisions of articles 213-214 Fiscal Procedure Code, subsequently corroborated by the provisions governing enforcement acts and their relationship with the precautionary measures. As well as the Order of the President of the National Agency for Fiscal Administration (O.P.N.A.F.A.) no 2.546/2016 for approval of the Procedure for the application of the precautionary measures by the competent tax authorities and for the approval of the models, the use and the keeping of some forms, published in the Official Gazette of Romania no 703 of September 9, 2016) and carry out the forced execution procedure are called tax executors who perform a function involving the exercise of the state authority during the exercise of their duties.

\section{The legal statute of tax executors}

\subsection{The legal definition}

The fiscal provisions expressly regulate the institution of the "tax executor", which is the person expressly empowered by special law to carry out the forced execution procedure of the fiscal obligations as a way of capitalizing on the receivables due to the general budget.

Thus, according to point 22 article 1 Fiscal Procedure Code, the tax executor is the person within the executing body responsible for enforcing the enforcement. And, first thesis of paragraph (1) article 223 establishes that forced execution is done by the competent enforcement body through tax executors.

According to the implementing rules (See O.P.N.A.F.A. no 1.099/2016 on the cards issued to the tax executors who carry out the precautionary measures and carry out the forced execution procedure in accordance with the provisions of Law no 207/2015 on the Fiscal Procedure Code, 
published in the Official Gazette of Romania no 239/03.31.2016) in the matter, the tax executors are persons employed within the enforcement body, within the structures authorized to carry out the precautionary measures and execute the forced execution procedure, designated by their manager to carry out the precautionary measures and carry out the forced execution procedure.

Under article 223 par. (1) Second thesis Fiscal Procedure Code corroborated with Order of the President of the National Agency for Fiscal Administration (O.P.N.A.T.A.) no 1.099/2016, the quality of the tax executor is attested by the service card, namely - the fiscal executor's card - which the tax executor must present in the performance of his activity.

Corroborating the provisions that legally define the tax executor with the provisions of article 341 Fiscal Procedure Code, as well as with the provisions of article 2 and article 6 of the Law no 188/1999 on the Civil Servants' Statute, republished (published in the Official Gazette of Romania no 365/05.29.2007), we find that the tax executors are civil servants whose legal regime is regulated by Law no 188/1999.

Thus, according to par. (1) article 341 Fiscal Procedure Code, in the exercise of their duties, civil servants (regarding the concept of civil servant and public office, see Buzatu 2011, 1822; Buzatu 2012, 13; Păiuşescu and Buzatu 2011, 96; Popescu 2012, 209; Tomescu 2015, 190; Tomescu 2016, 103; Vedinaş 2009, 465) within the fiscal bodies are invested with the exercise of the public authority and are protected by the law.

The civil servant is the legal person invested by appointment in a public position within the structure of an administrative public service, in order to fulfill its competence (Vedinaş 2009, 469).

In conclusion, we appreciate that the tax executor is the holder of a specific public function, subject to the general statute, being a public execution officer, invested with the exercise of the state authority.

\subsection{The tax executor versus the court executor}

\subsubsection{Rule}

The status of tax executors, who are civil servants operating within state bodies, is quite different from that of court executors (Oprina and Gârbuleţ 2013, 1011).

This different legal status of the two categories of executors is based on the legal relations governing the two branches of law. Thus, the civil legal relationship is that social, patrimonial or non-patrimonial relationship governed by the civil law rule (Beleiu 1999, 76 apud Oprina and Gârbuleţ 2013, 1012), while the tax legal relationship is that tax relationship that arises in the process of allocating part of the national income and redistributing some taxpayer's income, for the purpose of setting up state funds (Şaguna and Şova 2006, 3-4 apud Oprina and Gârbuleţ 2013, 1012). Also, the difference in the legal status of the two categories of executors is also based on the difference in subjects in the two legal relationships. In the civil legal report, its subjects are natural persons and legal entities, which can be determined on the basis of civil relations that contain an absolute right or a relative right, while in the tax law report, the active subject is the state, represented centrally by the Ministry of Public Finance and the National Agency for Fiscal Administration (N.A.F.A.) and at local level the administrative-territorial units subordinated to N.A.F.A. and the passive subject is the taxpayer, as a rule, the natural or legal person (Oprina and Gârbuleţ 2013, 1012).

Thus, as it was also noted in judicial practice (see, largely, civil decision no 188/2012 of the Argeş Tribunal, which we find also in the Romanian Magazine of forced execution no 1/2012), the execution of a fiscal obligation by the common law court executor is unlawful because "forced execution of the fiscal obligations is done by enforcement bodies organized at the level of county or local tax authorities through the tax executors, the procedural rules mentioned above having a public order character, in relation to the purpose pursued by the provisions of Fiscal Procedure Code, respectively good administration of state and/ or local budget debts. Fiscal forced execution is governed by special rules, not only in terms of competence but also of the procedural steps required, and observing in this respect that there are a number of rules that facilitate the enforcement of fiscal obligations. It is the case of the beginning of enforced enforcement, which, in 
respect of the tax claims, does not require the intervention of the courts, and it is not necessary to approve the forced execution imposed by the norms of common law - art. $373^{1}$ Civil Procedure Code".

Moreover, according to article 623 Civil Procedure Code and art. 1 Law no 188/2000, "enforcement of any enforceable title, except those relating to revenues due to the general budget or the budget of the European Union and the budget of the European Atomic Energy Community, shall be performed only by the court executor, even if by special laws it is otherwise ordered".

Consequently, the rule in this matter is that the forced execution is done by the competent enforcement body through tax executors, so the execution of a tax claim by the common law court executor is unlawful.

\subsubsection{Exception}

However, in the case of a forced execution competition, the new tax provisions expressly regulate exceptional situations when the tax executor will not perform the forced execution procedure, $b u t$ the court executor.

Thus, the new fiscal texts, in par. (13) to (15) article 220 Fiscal Procedure Code (13), provide the following:

"(13) If the execution has been started on the same income or assets of the debtor, both for the execution of the enforcement titles regarding the tax receivables, as well as for the securities executed under the conditions laid down by other legal provisions, forced execution is connected and is carried out, according to the provisions of this Code, by the enforcement body provided by it. In this case the competence belongs to the fiscal body holding the higher tax receivable. In the event of a conflict between the forced execution tax authorities having as object the connection of the execution, the provisions of articles 41-43 (the provisions of articles 41-43 Fiscal Procedure Code regulates the conflict of jurisdiction between tax authorities).

(14) The provisions of paragraph (13) shall not apply in the following situations:

(a) if the value of the debtor's assets covers only the claims of other creditors holding collateral with a priority status over the tax (fiscal) creditor;

(b) if the forced execution initiated by the court executor is at an advanced stage and the recovery of the assets subject to forced execution ensures full recovery of the tax receivables (fiscal obligations).

(15) Where enforcement of a forced execution by a court executor and a fiscal executing body has been commenced on the same assets of the debtor at the request of the person concerned or of any of the executors, the competent court shall order the connection of the forced execution under the terms of this Article. The provisions of art. 654 par. (2) to (4) of the Code of Civil Procedure, republished, shall apply accordingly".

We observe that the provisions of the Fiscal Procedure Code are complemented by the rules of common law laid down in the Civil Procedure Code, republished. Thus, in the light of the provisions of art. 654 Code of Civil Procedure par. (2) to (4) in conjunction with par. (13) to (15) article 220 Fiscal Procedure Code, if the court orders the connection of the execution, the court, through the closing, shall also rule on the execution costs incurred until the time of the connection. At the same time, the court will order the sending of the joined files to the designated executor according to the law, which may also be the court executor, to the detriment of the tax executor, if two conditions are met cumulatively:

1) Forced execution by the court executor is in a more advanced stage

2) The recovery of assets subject to forced execution ensures full recovery of fiscal obligations.

Once joined, the execution procedure will continue from the most advanced tracking act. And the discontinuation of any of the pursuing creditors after the connection will not be able to prevent the continuation of execution from the most enforceable act (in this regard, par. (3) to (4) article 654 Code of Civil Procedure). 


\section{The duties of the tax executor}

\subsection{The legal basis for fulfilling the duties of a tax executor}

According to article 223 par. (2) Fiscal Procedure Code, the tax executor is empowered before the debtor and third parties by the fiscal executor's card service (see article 5 O.P.N.A.F.A. no 1.099/2016) and the delegation issued by the enforcement body.

The service card attests to the power of the tax executor in front of the debtor or of the third parties, which implies the exercise of the state authority, granted to him to carry out his duties according to the law (paragraph (1) article 3 O.P.N.A.F.A. no 1.099 /2016), a card that the tax executor must present in the exercise of his activity (second thesis of paragraph (1) article 223 Fiscal Procedure Code).

Thus, the tax executor is empowered to carry out the precautionary measures and carry out the forced execution procedure.

The service card is valid only with the delegation issued by the enforcement body, the structure authorized to carry out the precautionary measures and execution of the forced execution procedure in special cases (see paragraph (2) article 3 O.P.N.A.F.A. no 1.099 /2016).

\subsection{Powers of the fiscal executor}

According to article 223 par. (3) Fiscal Procedure Code corroborated with article 4 par. (1) O.P.N.A.F.A. no $1.099 / 2016$, in the performance of its duties, on the basis of the service card and the delegation, the tax executor may:

a) Enter any business premises of the debtor, a legal person, or in other premises where he keeps his property for the purpose of identifying the assets or valuables that can be executed as forced, and to analyze the debtor's records for the purpose of identifying third parties owe or hold in custody income or property of the debtor;

b) To enter all the premises in which the debtor is in possession of the goods or values, the natural person, as well as to search all the places where he keeps his possessions;

c) To request and inspect any material or document that may constitute evidence in determining the debtor's property;

d) Apply the seals on the goods, drawing up a report in this respect;

e) To find contraventions and to apply sanctions according to the law.

Under par. (4) Article 223 Fiscal Procedure Code in conjunction with par. (2) O.P.N.A.F.A. no 1.099/2016, the tax executor may enter the premises which represent the residence or the residence of a natural person with his consent, and in case of refusal, the enforcement body requests the authorization of the competent court according to the provisions of the Civil Procedure Code, republished.

Access of the tax executor to the dwelling, business premises or any other room of the debtor, a natural or legal person, may take place between $06.00-20.00$ on any working day. Execution can begin on the same day or the next day. In cases duly justified by the danger of the alienation of goods, access to the debtor's premises may take place at other times than those mentioned, as well as on non-working days, on the basis of the competent court authorization.

According to par. (3) to (4) article 651 Civil Procedure Code, the enforcement authority (under first thesis of par. (1) article 651 Civil Procedure Code, at the date of notification of the executing body, the court of enforcement shall be the court in whose jurisdiction it is located the domicile or the debtor's office, unless the law otherwise provides) shall settle applications for the enforcement of enforced execution, appeals against execution, as well as any other incidents occurring during enforced execution, except those provided by law in the jurisdiction of other courts or authorities. In all cases, the enforcement instance shall be pronounced by a writ of execution, which may be appealed only on appeal, within 10 days of communication, unless otherwise provided by law.

In the absence of the debtor, or if he refuses access to any of the premises, the tax executor may enter them in the presence of a police or gendarmerie representative or other public servant and 
two major witnesses (see par. (6) Article 223 Fiscal Procedure Code corroborated with par. (4) Article 4 O.P.N.A.F.A. no 1.099/ 2016).

\subsection{Liability of the tax executor}

Starting from the legal provisions (article 341 Fiscal Procedure Code corroborated with the provisions of Law no 188/1999 and the provisions of article IX of Government Emergency Ordinance no 46/2009 regarding the improvement of fiscal procedures and the reduction of tax evasion, approved with amendments and completions by Law no 324/2009, published in Official Gazette of Romania no No 347 from May 25, 2009), we find, as a rule, that the breach by the civil servants of the duty of service entails the patrimonial, disciplinary or contravention liability, as the case may be, and only by way of exception, the civil or criminal liability.

Thus, according to article 341 par. (2) Fiscal Procedure Code, the state and the administrativeterritorial units are liable for the damages caused to the taxpayer by the civil servants within the fiscal bodies, in the exercise of their duties.

Article 76 of Law no 188/1999 provides that any person who considers himself or herself to be harmed by his or her right or legitimate interest may apply to the court, under the law, against the public authority or institution which issued the document or who refused to resolve the request concerning a subjective right or a legitimate interest. If the action is admitted and the guilt of the civil servant is established, the person concerned shall be obliged to pay the damages, jointly with the public authority or institution. However, the civil servant's legal liability cannot be enforced if he has complied with the legal provisions and administrative procedures applicable to the public authority or institution in which he operates.

Corroborating first thesis of par. (3) article 341 Fiscal Procedure Code with article 77 Law no $188 / 1999$, we find that the violation by public officials - fiscal executors - of the duties corresponding to their public office and of the professional and civic norms stipulated by the law constitute a disciplinary offense and attract their disciplinary liability.

At the same time, according to article 83 par. (1) Law no 188/1999, civil servants shall be liable for contravention if they have committed a contravention during and in connection with the service duties (according to par. (2) Article 83 Law no 188/1999).

In light of the provisions of second thesis of par.(3) article 341 Fiscal Procedure Code, during the period of their activity, the persons who occupy or have held public dignity, senior civil servants, civil servants and contract staff of the Ministry of Public Finance and of the National Agency for Fiscal Administration, both at central and at level territorial jurisdiction shall not be liable for civil or criminal liability, as the case may be, only if the courts find the fulfillment or omission of their guilty, gross negligence or serious negligence, of any act or fact related to the exercise, under the law, of their attributions (see article IX par.(1) of Government Emergency Ordinance no 46/2009).

\section{Conclusions}

According to the special provisions existing in the field of taxation, the forced execution of fiscal obligations is carried out, as a rule, by fiscal executors, and the procedure is not preceded by another judicial procedure. Furthermore, only in special cases, provided by law, the court executor can fulfill the fiscal obligation forced execution procedure. The fiscal executor is a civil servant that is liable for his actions and must always present his service card with which he is empowered to carry out the forced execution procedure and, also the precautionary measures.

\section{References}

Buzatu, Nicoleta-Elena. 2011. "The public officer - the active subject of a crime.” In CKS E-Book 2011, pp. 1822-1826. Bucharest: Pro Universitaria Publishing House.

Buzatu, Nicoleta-Elena. 2012. "Aspects regarding the penal responsability of public officers." In AGORA IJJS, no 1, pp. 1316..Oradea: Agora University Press. 
Civil decision no 188/2012 of the Argeş Tribunal, which we find also in the Romanian Magazine of forced execution no 1/2012, Universul Juridic Publishing House, Bucharest 2014.

Deleanu, Ion. 2005. Civil Procedure Treaty. Volume II. Bucharest: All Beck Publishing House.

Government Emergency Ordinance no 46/2009 regarding the improvement of fiscal procedures and the reduction of tax evasion.

Law no 134/2010 on the Civil Procedure Code, published in the Official Journal of Romania (Part I, 545) on 3 August 2012.

Law no 188/2000 regarding the court executors, published in the Official Journal of Romania, no. 559 on 10 Nov. 2000.

Law no 207/2015 regarding the Fiscal Procedure Code, published in the Official Journal of Romania, no 547 of 23 July 2015.

Law no 277/2015 regarding the Fiscal Code, published in the Official Journal of Romania, no 688 of 10 Sept. 2015.

Leş, Ioan. 2005. Civil Procedure Law Treaty. Bucharest: All Beck Publishing House.

O.P.N.A.F.A. no 1.099 / 2016 on the cards issued to the tax executors who carry out the precautionary measures and carry out the forced execution procedure in accordance with the provisions of Law no 207/2015 on the Fiscal Procedure Code.

Oprina, Evelina, and Garbulet, Ioan. 2013. Theoretical and Practical Treaty of forced execution. General Theory and Exceptional Procedures. Volume I. Bucharest: Universul Juridic Publishing House.

Oprina, Evelina.2007. Enforced Execution in civil proceedings. Bucharest: Universul Juridic Publishing House.

Order of the President of the National Agency for Fiscal Administration (O.P.N.A.F.A.) no 2.546 / 2016 for approval of the Procedure for the application of the precautionary measures by the competent tax authorities and for the approval of the models, the use and the keeping of some forms.

Păiușescu, Anca; Buzatu, Nicoleta-Elena. 2011. "Communication between the civil servants and the citizens." In Analele Universității Seria Drept, Revista Centrului de Cercetări Juridice și Administrative no 1, pp. 96-98. Bucharest: Pro Universitaria Publishing House.

Popescu, Agata Mihaela. 2012. Administrative Law. The general part. Individual study manual. Bucharest: Pro Universitaria Publishing House.

Şaguna, Dan Drosu, and Sova, Dan. 2006. Tax Law. Bucharest: C.H. Beck Publishing House.

Tomescu, Mădălina. 2015. Administration Science. Bucharest: Pro Universitaria Publishing House.

Tomescu, Mădălina. 2016. The Deontology of the Civil Servant. Bucharest: Pro Universitaria Publishing House.

Vedinaş, Verginia. 2009. Administrative Law. 4th edition. Bucharest: Universul Juridic Publishing House.

Zilberstein, Savelly, and Viorel Mihai Ciobanu. 2001. Forced execution treaty. Bucharest: Lumina Lex Publishing House. 